\title{
Effect of Inclusion Rate of Effective Microbes (Em) On Growth Rate of Lambs Fed Low Protein Diet
}

\author{
Deribe Gemiyo*, Shimelis Mengistu, Fitsum Tessema, Melese Yilma, Shewangizaw Wolde and Tewodros \\ Getachew
}

South Agricultural Research Institute, Areka Agricultural Research Centre, Ethiopia

Received: November 02, 2017; Published: November 10, 2017

*Corresponding author: Deribe Gemiyo, South Agricultural Research Institute (SARI), Areka Agricultural Research Centre, P.0. Box 79, Areka, Ethiopia; Tel: 4655200468; 924444125; Email: deribeg2000@yahoo.com

\section{Abstract}

Background: A great majority of animal feed is roughage based (poor in quality) in crop-livestock mixed farming system of southern Ethiopia. EM is considered as one of the options that may improve poor quality feeds dominant in the area. A study was conducted to determine inclusion rate of effective microbes (EM mixed with wheat bran, EM-bokashi) on growth rate of lambs fed low protein diets at Dubo Mante research sub-station.

Method: Twenty four (24) post pubertal male sheep of similar age (about 12 months age) with an average weight of $14.1 \pm 1.74 \mathrm{~kg}$ were purchased from local market. The lambs were assigned randomly to one of the four treatments (T1=0\% EM, T2=1\% EM, T3=3\% EM, T4=5\% EM). Water and Rhodes (Chlorias gayana) hay were offered ad libtum.

Results: EM-bokashi supplemented at $5 \%$ resulted in significantly $(\mathrm{P}<0.05)$ higher intake and growth rate in terms of weight gain than those supplemented with 3\% EM-bokashi. Likewise, lambs supplemented with 3\% EM-bokashi showed significantly $(\mathrm{P}<0.05)$ higher growth rate than those supplemented with $1 \%$ while the difference between $1 \%$ and the control $(0 \%)$ is not significant. Similarly, lesser disease occurrence was observed in lambs supplemented with EM-bokashi than untreated animals. Supplementing 5\% EM-bokashi added 51.2\% and $43.6 \%$ additional economic incentives over the control and 1\% EM level, respectively. Generally, both weight gain and profitability increased as level of EM supplementation advanced.

Conclusion: Additional weight in terms of daily weight gain and profitability considered in this experiment are crucial in the livelihood of small-scale farmers. Hence, 5\% EM-bokashi could be recommended as biologically and economically profitable inclusion level for lambs fed on low protein diet under smallholder farmer's management conditions.

Keywords: Lambs; Growth; Roughage; Strategic supplementation; Effective micro-organisms

Abbreviations: BED: Breeding Evaluation and Distribution; SAS: Statistical Analysis System; EM: Effective Microorganisms; CBR: Cost Benefit Ratio

\section{Introduction}

Small ruminants are integral components of crop-livestock mixed and serve as investment and insurance due to high fertility, short generation interval and their ability to produce in limited feed resource and their adaptation in harsh environment Tsedeke [1], Deribe et al. [2] Smallholder farmers raise sheep and goats as a major source of meat and immediate cash income in different parts of the country. Despite large number and importance of sheep in the areas, productivity is low due to a number of factors among others feed shortage both in quality and quantity, and health constraints Tibbo et al. [3-5]. The limitation in production due to shortage of feeds and poor nutrition is usually profound in areas where high seasonal dynamics in feed sources, fragile ecologies and environments exposed degradation.
Moreover, a great majority of feeds in crop-livestock mixed farming systems is roughage feeds with low feed values. Improving feeds and nutrition through technologies that improves rumen fermentation of roughage feeds, improves protein supply to micro organisms and reduce methane emission is important to boost the overall productivity, health, and well-being of sheep flocks Woju [6]. In this regard, use of effective microbes (EM-bokashi) for better management of crop residues is thus imperative Safalaoh and Smith [7]. EM is a mixture of groups of organisms that has a reviving effect on the natural environment Daly and Stewart [8] and consists of around 80 species of selected beneficial microorganisms including lactic acid bacteria, yeasts, photosynthetic bacteria, and actinomycetes, among other types of microorganisms such as fungi $\mathrm{Xu}[9]$. 
The technology of Effective Microorganisms commonly termed (EM Technology) was developed in the 1980's at the University of the Ryukyus, Okinawa, Japan. The inception of the technology was based on blending a multitude of microbes, and was subsequently refined to include three principal types of organisms commonly found in all ecosystems, namely Lactic Acid bacteria, Yeast Actinomyces and Photosynthetic bacteria Higa [10]. The use of EM in animal husbandry is clearly identified in many parts of the world. A study in Asia where EM was first introduced and is used extensively reported the successful use of EM in poultry and swine units Konoplya and Higa [11] and is added to feed and sprayed for sanitation in these units. Research in South Africa also highlight the potential of using EM for treating pig manure Hankoen et al. [12], which promotes growth of the animals.

According to Yohgzhen and Weijiong [13] and Anon (2002) EM has shown to reduce odour of livestock waste and accelerates conversion into manure compost Yohgzhen and Weijiong [13]. EM as additive improves physiological activity in animals and better feed conversion efficiencies Konoplya and Higa [11]; Safalaoh \& Smith [12]. EM prepared mixing with wheat bran (EM-bokashi), creates Probiotics, which increases quantity, availability, digestibility and assimilation of nutrients in animal body. EM equilibrates the micro-flora within the intestines of the animals and consequently improves feed conversion and weight gain due to increased nutrient assimilation. EM reduces production of methane suppresses disease-inducing organisms Higa [10]. In Ethiopia, the assumption that non-conventional supplements such as EM could help reduce high price of concentrates that had been used rumen manipulation and efficient use of fibrous feed materials as., Therefore, this study was designed to inclusion level of EM to be included as an additive in low quality feeds to boost small ruminant production in croplivestock mixed farming systems of southern Ethiopia.

\section{Materials and Methods}

\section{Study area Descriptions}

The study was conducted at Areka Agricultural research Centre, Mante Dubo experimental sub-station, located at about $305 \mathrm{kms}$ from Addis Ababa and $200 \mathrm{kms}$ from the regional city, Hawassa, through Wolaita soddo road. The station is located at an altitude of 1711 meters above sea level (masl) and situated at N 07' 06.4312' and E037' 41.688'. The station has 39 hectares of land, of which about 27 ha is used for grazing. The rainfall of the area is 100-1200 $\mathrm{mm}$ with bimodal type of rainfall, the heavy rainy season from July to September while light rainy between March to May. Production of forage such as 'desho' (Pennisetum pendicellatum), Napier grass (P. pedicellatum), rhodes grass (Chlorias gayana) and others is commonly produced and distributed for Dorper sheep breeding, evaluation and distribution (BED) site to improve mutton yield of local sheep breeds. There are huge crop leftovers and grass hays produced for livestock feeding during dry season but are poor in quality.

\section{Experimental Animal and Housing Arrangement}

Individual pen prepared and partitioned using wooden poles and timber materials. Twenty four (24) post pubertal male lambs of similar age (less than one year) with an average weight of $14.1 \pm 1.74$ kg were purchased from the local market, Doyogena woreda of southern region. The lambs were kept in quarantine for fifteen days for acclimatization and to monitor their health condition and ensure that they are protected from diseases. Six (6) lambs were assigned for each treatment and grouped (blocked) by their weight and put under each feed treatment. All lambs were dewormed with recommended dose of Albendazole before the trial started.

EM of different treatment level was added as a supplementary feed with a recommended feed intake percentage for small ruminants. Fifteen weeks weight gain data were collected. Feed troughs were made empty 1-2 hours before the next feeding. The basal feed, Rhodes hay (with $85 \%$ DM, 7.13\% CP, 70.24\% NDF and $60.61 \%$ in vitro digestibility) offered ad libitum and lambs were watered twice a day. Three hundred gram of wheat bran (as feed basis mixed EM, EM-bokashi) was offered as a supplement for all experimental animals under each treatment. The treatments were, T1=control (without EM-bokashi), T2= 1\% EM-bokashi, T3=3\% EM-bokashi and T4=5\% EM-bokashi. The supplementation was expected total feed intake (600 gram) as feed basis in the total mixed ration.

\section{Data Collection and Analysis}

Weight (initial weight, weekly weight and final weights), health condition and other disease records were collected. Frequency of disease occurrence was analyzed with descriptive statistics. The data were analyzed using General linear Model of Statistical Analysis System (SAS, 2008). Means were separated using Tukey's test at $\mathrm{P}<0.05$.

\section{Results and Discussion}

There was great variation in weight gain between sheep fed different level of EM-bokashi supplementation. EM-bokashi of 1\% supplementation was not significantly $(P>0.05)$ different from the control (without EM-bokashi supplementation). Lambs fed on 5\% EM-bokashi supplementation showed the highest body weight gain as compared to other supplementation levels. The highest level of supplementation $(5 \%)$ was in line with other literatures done on small stock and poultry. Increasing EM-bokashi supplementation level beyond $5 \%$ has not been suggested. The body weight increase with the increasing level of EM-bokashi supplementation in this experiment agrees with other experiments conducted in Debrezeit Agricultural research centre with more level of supplementation in water solution Woju [6] and in Nepal Dahal [14]; Daly et al. [8]. This could be due to improved CP content of the mixture in the $5 \% \mathrm{EM}$ bokashi in comparison with other level of supplementation Asfaw [15]; Woju [6] (Table 1).

Table 1: Mean daily weight gain (g/day) of lambs supplemented with EM-bokashi fed on low protein diet.

\begin{tabular}{|c|c|c|c|c|}
\hline Treatment & $\mathbf{N}$ & Mean & Std. Error & $\mathbf{9 5} \% \mathbf{C I}$ \\
\hline $\begin{array}{c}\text { 1 (Control, with EM- } \\
\text { bokashi) }\end{array}$ & 6 & $0.27^{\mathrm{c}}$ & 0.031 & $0.19-0.35$ \\
\hline 2 (1\% EM-bokashi) & 6 & $0.32^{\mathrm{c}}$ & 0.031 & $0.24-0.4$ \\
\hline 3 (3\% EM-bokashi) & 6 & $0.43^{\mathrm{b}}$ & 0.031 & $0.35-0.51$ \\
\hline 4 (5\% EM-Bokashi) & 6 & $0.53^{\mathrm{a}}$ & 0.031 & $0.45-0.61$ \\
\hline
\end{tabular}


Six types of disease were diagnosed during the experimental period but no death occurred. Systemic infection was diagnosed on all experimental animals under each treatment group with more frequency under control group (3 times) followed by $1 \%$ EMbokashi (2 times). But it was the same in the other two levels of treatments (3\% and 5\% EM-bokashi supplementation) (1 time). Pneumonia was diagnosed with equal frequency in the control, $1 \%$ and $5 \%$ but not in the 3\% EM-bokashi supplementation. Orf occurred with similar frequency and duration in all treatment groups on almost all experimental lambs. The lower frequency of occurrence of systemic infection under the two higher level of supplementation may indicate the effect of EM-bokashi on improving health condition of animals Bruchem $[16,17]$. The result is also in line with the findings of Woju [6] who reported reduced disease and methane emission from EM supplemented animals (Table 2).

Table 2: Mean daily weight gain (g/day) of lambs supplemented with EM-bokashi fed on low protein diet.

\begin{tabular}{|c|c|c|c|c|}
\hline \multirow{2}{*}{ Description } & \multicolumn{3}{|c|}{ Level of EM-bokashi supplementation } \\
\cline { 2 - 5 } & T1 & T2 & T3 & T4 \\
\hline Frequency of systemic infection & 3.00 & 2.00 & 1.00 & 1.00 \\
\hline Frequency of pneumonia & 1.00 & 1.00 & 0.00 & 1.00 \\
\hline Frequency of heart water & 1.00 & 0.00 & 0.00 & 1.00 \\
\hline Frequency of skin lesion & 0.00 & 0.00 & 1.00 & 0.00 \\
\hline Frequency of pink eye disease & 0.00 & 1.00 & 1.00 & 1.00 \\
\hline Frequency of orf & 1.00 & 1.00 & 1.00 & 1.00 \\
\hline
\end{tabular}

Table 3: Growth rate of lambs fed low protein diet and supplemented with EM-bokashi.

\begin{tabular}{|c|c|c|c|c|c|c|c|c|c|c|}
\hline Treatment & $\begin{array}{l}\text { Average } \\
\text { initial wt }\end{array}$ & Wt 15 & Wt 30 & Wt 45 & Wt 60 & Wt 75 & Wt 90 & Wt 105 & $\begin{array}{l}\text { Average } \\
\text { final wt }\end{array}$ & Wt gain \\
\hline $\mathrm{T} 1$ & $14.1^{\mathrm{a}}$ & $16.8^{\mathrm{a}}$ & $16.9^{\mathrm{a}}$ & $17.8^{\mathrm{a}}$ & $18.1^{\mathrm{a}}$ & $19.2^{\mathrm{a}}$ & $19.7^{\mathrm{a}}$ & $20.1^{\mathrm{a}}$ & $18.2^{\mathrm{c}}$ & $4.1^{c}$ \\
\hline $\mathrm{T} 2$ & $14.3^{\mathrm{a}}$ & $13.1^{\mathrm{b}}$ & $13.5^{\mathrm{b}}$ & $13.9^{\mathrm{b}}$ & $14.6^{\mathrm{b}}$ & $15.4^{c}$ & $16.5^{\mathrm{b}}$ & $18.4^{\mathrm{b}}$ & $18.9^{c}$ & $4.7^{c}$ \\
\hline T3 & $14.0^{\mathrm{a}}$ & $11.2^{c}$ & $11.8^{\mathrm{c}}$ & $12.6^{\mathrm{c}}$ & $13.6^{c}$ & $14.9^{c}$ & $16.4^{\mathrm{b}}$ & $18.2^{\mathrm{b}}$ & $20.5^{b}$ & $6.4^{\mathrm{b}}$ \\
\hline $\mathrm{T} 4$ & $14.0^{\mathrm{a}}$ & $14.2^{\mathrm{b}}$ & $14.55^{b}$ & $14.9^{\mathrm{b}}$ & $16.2^{\mathrm{b}}$ & $17.6^{\mathrm{b}}$ & $19.4^{\mathrm{a}}$ & $21.4^{a}$ & $22.0^{\mathrm{a}}$ & $7.9^{\mathrm{a}}$ \\
\hline
\end{tabular}

Means with the different letters $(a, b, c)$ are not significantly different at $5 \%$ level of significance; $\mathrm{Wt}$, weight

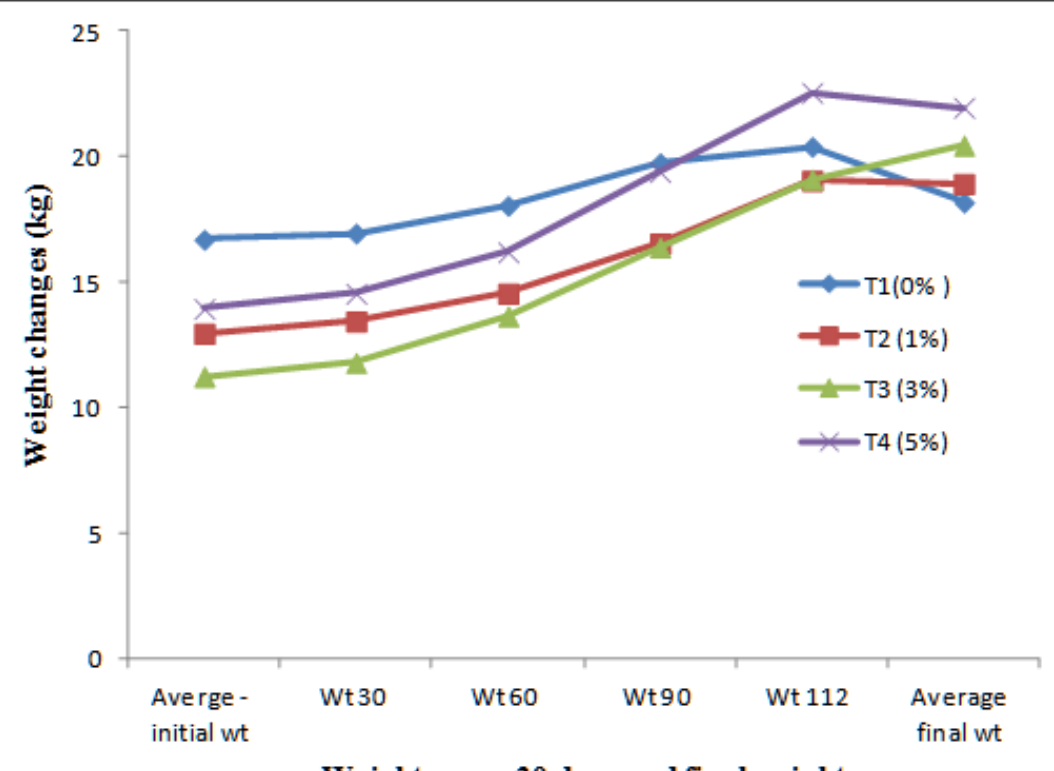

\section{Weight every 30 days and final weight}

Figure 1: Trends of weight changes over experimental period of lambs supplemented with effective microbes (EM-bokashi) and fed on low protein diets.

\section{Growth Rate}

The average initial weight of the lambs used in this experiment was not significant among the treatments (Table 3). At the beginning of the experiment due to adaptation or the depressing role of EM-bokashi, the control was significantly higher compared to treatment effects up until 105 days of age while the final weight of the lambs supplemented with the highest level (5\%) of EMbokashi was significantly higher compared with T3. Likewise, 
sheep treated with T3 had higher final growth rate compared with T2 while the differences between T2 and the control was not significant in the majority of the cases. The results agree with other reports Safalaoh \& Smith [12]; Woju [6]. The fact that rumen fermentation improved due to EM supplementation, productivity per unit feed improves under EM supplementation Woju [6] (Table 3).For the first 90 days, lambs fed on diets without of EM-bokashi supplementation were better than those supplemented with EMbokashi (Figure 1). However, when lambs adapted to experimental diets the differences between supplemented and not supplemented become more profound. The results agree with reports of Safalaoh and Smith [7] and Woju [6] (Figure 1).

\section{Partial Budget Analysis}

Profitability was calculated using Cost Benefit Ratio (CBR). In this economic analysis labour cost incurred for feeding experimental animals during the trial period was not considered as it exaggerates the expense. EM (liquid) used in this experiment was purchased from Woljeejii Agricultural Industry P.L.C and labour cost for bokashi preparation was included in bokashi purchase cost. As it is shown in the table below, $5 \%$ EM-bokashi supplementation is profitable under this experiment. The emerging industrial options globally and in areas where this study conducted are an opportunity to efficiently utilize the technology options Woju [6] (Table 4).

Table 4: Estimation of partial budget for lambs supplemented with EM-bokashi fed on low protein diet.

\begin{tabular}{|c|c|c|c|c|}
\hline \multirow{2}{*}{ Description } & \multicolumn{4}{|c|}{ Treatment } \\
\cline { 2 - 5 } & T1 & T2 & T3 & T4 \\
\hline Initial weight & 14.08 & 14.26 & 14.03 & 14.03 \\
\hline Final weight & 18.18 & 18.92 & 20.46 & 21.96 \\
\hline Cost of EM-bokashi/head & 0 & 10.72 & 32.32 & 53.76 \\
\hline $\begin{array}{c}\text { Animal purchase cost/ } \\
\text { head }\end{array}$ & 436.33 & 442.01 & 434.78 & 434.78 \\
\hline Total cost (A) & 436.33 & 452.73 & 467.1 & 488.54 \\
\hline $\begin{array}{c}\text { Animal selling price/ } \\
\text { head (B) }\end{array}$ & 563.43 & 586.52 & 634.21 & 680.71 \\
\hline
\end{tabular}

\section{Conclusion}

Small ruminants, particularly sheep, are dependent on hay and crop residues in crop-livestock mixed farming systems. Animals lose weight during the dry season as most of the feeds in this period are poor in quality. Technological options that improve feed intake and rumen digestibility of these bulk feeds is essential to boost productivity. In this experiment, both weight gain and growth rate increased as level of EM-bokashi supplementation increased. Inclusion of EM-bokashi at $5 \%$ has also been supported with economic profit. Moreover, the frequency of disease occurrence reduced with increased level of EM-bokashi supplementation. Hence, EM-bokashi supplementation at $5 \%$ level is biologically and economically profitable for lambs fed on low protein diet under smallholder farmer's management conditions.

\section{Acknowledgement}

SARI, Southern Agricultural Research Institute, funded this study and is dully acknowledged. Areka Research centre provided facilities and financial support to undertake the experiment.

\section{References}

1. Tsedeke K (2007) Production and marketing systems of sheep and goats in Alaba, University of Hawassa, Southern Ethiopia.

2. Deribe G, Girma A, Azage T (2014) Influences of non-genetic factors on early growth of Adilo lambs under farmer's management systems, southern Ethiopia. Tropical Animal Health and Production 46(2): 323329.

3. Tibbo M (2006) Productivity and Health of indigenous sheep Breeds and Crossbreds in the Central Ethiopian Highlands. Faculty of Medicine and Animal Science department of Animal Breeding and Genetics. Swedish University of Agricultural Sciences, Uppsala, Sweden.

4. Getahun L (2008) Productive and Economic performance of Small Ruminant production in production system of the Highlands of Ethiopia. University of Hohenheim, Stuttgart-Hoheinheim, Germany.

5. Kocho T, Girma A, Tegegne A, Berhanu G (2011) Marketing value chain of smallholder sheep and goats in crop-livestock mixed farming system of Halaba, Southern Ethiopia. Small Ruminant Research. 96: 101-105.

6. Woju CW (2012) Impact of effective microorganisms ${ }^{\mathrm{TM}}\left(\mathrm{EM}^{\mathrm{TM}}\right)$ on nutrient content of feeds, feed intake, digestibility, growth and mixed internal parasitic load on local sheep at Debre Zeit, Ethiopia. International Conference and exhibition on Probiotics. Hilton San Antonio Airport, USA. Journal of Food Process Technology 3(10): 134-142.

7. Safalaoh ACL, Smith GA (2001) Effective Microorganisms (EM) as an alternative to antibiotics in broiler diet s: Effect s on broiler performance, feed utilization and serum cholesterol. In: Senanayake, YDA and Sangakkara UR (Eds). Proceedings of the $6^{\text {th }}$ International Conference on Kyusei Nature Farming, South Africa.

8. Daly MJ, Stewart DPC (1999) Influence of effective micro-organisms (EM) on vegetable production and carbon mineralization- a preliminary investigation. Journal of Sustainable Agriculture 14(3): 101-142.

9. Xu H (2000) Soil-root interface water potential in sweet corn as affected by organic fertilizer and microbial inoculants. In Xu H, Parr JF, Umemura H (Eds.), Nature Farming and Microbial Applications. the Haworth Press Inc, New York, USA, pp.139-156.

10. Higa T (1996) Effective Microorganisms: Their role in Kyusei nature Farming and Sustainable Agriculture. In JFm Parr, SB Hornick and ME Simpson (Eds.), Proceedings of the $3^{\text {rd }}$ International Conference on Kyusei Nature Farming. US Department of Agriculture, Washington DC, USA, p. 20-23.

11. Konoplya E, Higa T (2000) EM application in animal husbandry Poultry farming and its action mechanisms. In: Proceedings of the International Conference on EM Technology and Nature Farming, Pyongyang, DPR Korea.

12. Hanekon DJF, Schoonbee HJ (1999) A comparison of the effect of EM on the faecal bacteria loads in the water and on fish produced in pig cum fish integrated product ion units. In Proceedings of the $6^{\text {th }}$ International Conference on Kyusei Nature Farming, South Africa, Senanayake, YDA and Sangakkara (Eds.), Africa.

13. Yohgzhen N, Weijiong L (1994) Report on t he deodorizing effect of effective microorganisms in poultry production. Beijing, China p. 4.

14. Dahal BK (1997) Effective Micro-organisms (EM) for Animal Production. Institute of Agriculture and Animal Science. Rampur Campus, Chitwan, Nepal, India.

15. Asfaw W (1997) Country report: Mbabany, Organized by CTA, OAU/ IBAR, The Ministry of Agriculture, Cooperative, Swaziland.

16. Bruchem JV (1998) Effect of beneficial micro-organisms (EM): First results from experimental farm De Ossekampen in Wageningen. Netherlands.

17. Sisay A (2006) Livestock production systems and available feed resources in different agro-ecologies of north Gonder zone, Alemaya Universit, Alemaya, Ethiopia. 


\begin{tabular}{ll} 
BIOMEDICAL & Assets of Publishing with us \\
RESEARCHES & Global archiving of articles \\
\hline & - Immediate, unrestricted online access \\
\hline
\end{tabular}

